\title{
Determination of Bioactive Compounds and Mineral Contents of Seedless Parts and Seeds of Grapes
}

\author{
M.M. Özcan ${ }^{1 *}$, F. Al Juhaimi², M. Gülcü ${ }^{3}$, N. Uslu ${ }^{1}$ Ü. Geçgel ${ }^{4}$
}

(1) Department of Food Engineering, Faculty of Agriculture, Selcuk University, 42031 Konya, Turkey

(2) Department of Food Science \& Nutrition, College of Food and Agricultural Sciences, King Saud University, Riyadh, Saudi Arabia

(3) Ministry of Food, Agriculture and Livestock Viticultural Research Station 59100, Süleymanpaşa, Tekirdag, Turkey

(4) Department of Food Engineering, Faculty of Agriculture, Namık Kemal University, Tekirdağ, Turkey

Submitted for publication: March 2017

Accepted for publication: July 2017

Keywords: Grape, bioactive compounds, antioxidant, fatty acid composition, mineral content

In this study, phenolic compounds, minerals, total flavonoids, total phenolic contents and antioxidant activities of the seedless parts (pulp+skin) and seeds of table and wine grapes were determined. Also, the total oil, tocopherol contents and fatty acid composition of seed oils of table and wine grapes were investigated. The highest total phenolic content of the grape pulp was found in Trakya ilkeren (199.063 $\mathrm{mg} / 100 \mathrm{~g}$ ), while total flavonoid and antioxidant activity of the pulp was determined at a high level in Red Globe $(6.810 \mathrm{mg} / \mathrm{g}, \mathbf{9 0 . 9 4 8 \%}$ ). Antioxidant activity, and the total phenolic and flavonoid contents of grape seeds varied between 86.688 and $90.974 \%, 421.563$ and $490.625 \mathrm{mg}$ GAE/100 g, and 90.595 and $145.595 \mathrm{mg} / \mathrm{g}$ respectively $(\mathrm{p}<\mathbf{0 . 0 5})$. Generally, the main phenolic compounds of all grape pulps and seeds were gallic acid, 3,4-dihydroxybenzoic acid, (+)-catechin and 1,2-dihydroxybenzene. In addition, the oil contents of grape seeds ranged from 5.275 (Çavuş) to $13.881 \%$ (Çınarlı karası) $(p<0.05)$. The major fatty acids of grape seed oils were linoleic, oleic and palmitic acid. The seed oil of the Trakya ilkeren variety was rich in tocopherols in comparison with the other varieties. The major minerals of both the seedless parts and the seeds were determined as $\mathrm{K}, \mathrm{Ca}, \mathrm{P}, \mathrm{S}, \mathrm{Mg}$.

\section{INTRODUCTION}

Grapes (Vitis spp.) belong to the Vitaceae family and are used mainly for their juice, especially in the wine industry (Lutterodt et al., 2011). The bioactive compounds, including simple phenolics, flavonoids, anthocyanins, stilbenes, proanthocyanidins and vitamin E, are important phytochemicals in grapes. Simple phenolic compounds of grapes are hydroxycinnamic acid (p-coumaric, caffeic, sinapic and ferulic acids) and hydroxybenzoic acid (gallic, gentisic, protocatechuic and p-hydroxybenzoic acids) (Georgiev et al., 2014; Shi et al., 2016). Several phenolic compounds are found in the skins, pulp and seeds of grapes (Nile et al., 2013). Most of these compounds have antioxidant properties, which play a significant role in human health because they reduce the oxidation of low-density protein, thereby decreasing the risk of heart disease and preventing cancer (Y1lmaz et al., 2015; Yalcin et al., 2016). The amount of phenolics is affected by the grapevine variety, climatic and geographical factors, cultural practices, and the stage of ripeness (Obreque-Slier et al., 2010; Farhadi et al., 2016).

A large amount of grape seeds are obtained from the waste of fruit products. The wastes of this industry represent about $50 \%$ to $60 \%$ of the raw fruit. On the other hand, grape seeds are used as a source of oil, with nutritional and bioactive constituents (Kamel et al., 1985; Hassanein \& Abedel-Razek, 2009). Grape seed oils obtained from grape by-products can be used for pharmaceutical and nutritional purposes due to their high levels of vitamin E and unsaturated fatty acids (Hassanein \& Abedel-Razek, 2009). These by-products contain some valuable substances, such as phenolics, fatty acids, tocopherols and minerals with potential applications in the food industry (Crews et al., 2006; Wie et al., 2009). Generally, grape seed oil is used in salad dressings, marinades, deep frying, flavoured oils, baking, massage oil and cosmetic products (Akın \& Altındişli, 2011).

The aim of this study was to investigate some physicochemical properties (soluble solid content, titratable acidity and maturation index of grapes; total dry matter of grape seeds), antioxidant activities, total phenolic and flavonoid contents, phenolic compounds and mineral contents of grapes (pulp+skin) and seeds, and the oil yields, fatty acid and tocopherol contents of grape seeds due to the importance of grapes and seeds as sources of bioactive compounds, oil, tocopherol and minerals.

*Corresponding author: E-mail address:mozcan@selcuk.edu.tr

Acknowledgements: The authors extend their appreciation to the International Scientific Partnership Program ISPP at King Saud University for funding this research work through ISPP\# 0015 


\section{MATERIAL AND METHODS}

Grapes (Çavuş, Çınarlı Karası, Kalecik Karası, Red Globe, Trakya Ilkeren, Yalova Incisi and Yapıncak) were obtained from the Viticulture Research Institute of Tekirdağ in Turkey. All varieties belong to Vitis vinifera. Their colours and properties are given in Table 1 .

\section{Sample extraction}

For the phenolic compounds and antioxidants, the seedless parts (pulp+skin) and seeds of the grapes were extracted according to Gomez-Alonso et al. (2007) with some modifications. About $2 \mathrm{~g}$ of each sample were added to $15 \mathrm{ml}$ of methanol:water:formic acid $(5: 4.85: 1.5, \mathrm{v} / \mathrm{v})$. The mixture was sonicated for $2 \mathrm{~min}$, followed by centrifugation at $4500 \mathrm{rpm}$ for $15 \mathrm{~min}$, after which the supernatants were collected. Then $10 \mathrm{ml}$ of $n$-hexane were added and mixed using a vortex apparatus. After the extract was concentrated at $50^{\circ} \mathrm{C}$ in a rotary evaporator, and after the dried extracts had been dissolved in $1.5 \mathrm{ml}$ of methanol, it was injected into HPLC.

\section{Physicochemical analysis}

The content of soluble solids, titratable acidity, maturation index and total dry matter were analysed according to Cemeroğlu (1992).

\section{Total phenolic content}

The total phenolic content of the grape pulp and seeds was determined by Folin-Ciacueltau (FC) reagent according to Yoo et al. (2004). About $10 \mathrm{~mL}$ of $\mathrm{Na}_{2} \mathrm{CO}_{3}$ solution and $1 \mathrm{ml}$ of Folin-Ciacueltau were mixed, and then completed with $25 \mathrm{ml}$ deionised water. After $1 \mathrm{~h}$, the total phenolic content was measured at $750 \mathrm{~nm}$ in a spectrophotometer. The results were given as mg gallic acid equivalent/100 g.

\section{Antioxidant activity}

The free radical-scavenging activity of the samples was determined using DPPH (1,1-diphenyl-2-picrylhydrazyl) according to Lee et al. (1998). The extract was mixed with $2 \mathrm{~mL}$ methanolic solution of DPPH. The mixture was shaken vigorously and allowed to stand at room temperature for 30 min. The absorbance was recorded at $517 \mathrm{~nm}$ by using a spectrophotometer.

\section{Determination of phenolic compounds}

Phenolic compounds were determined by a Shimadzu-HPLC equipped with a PDA detector and an Inertsil ODS-3 (5 $\mu \mathrm{m}$; $4.6 \times 250 \mathrm{~mm}$ ) column. As mobile phases, $0.05 \%$ acetic acid in water (A) and acetonitrile (B) mixture were used. The flow rate of the mobile phase and the injection volume were $1 \mathrm{ml} / \mathrm{min}$ at $30^{\circ} \mathrm{C}$ and $20 \mu \mathrm{l}$ respectively. The gradient program was as noted: 0 to $0.10 \mathrm{~min} 8 \% \mathrm{~B}$; 0.10 to $2 \mathrm{~min}$ $10 \% \mathrm{~B} ; 2$ to $27 \mathrm{~min} 30 \% \mathrm{~B} ; 27$ to $37 \mathrm{~min} 56 \% \mathrm{~B} ; 37$ to 37.10 $\min 8 \% \mathrm{~B}$; and 37.10 to $45 \mathrm{~min} 8 \% \mathrm{~B}$. The peak records were carried out at 280 and $330 \mathrm{~nm}$. The total running time for each sample was $60 \mathrm{~min}$. Phenolic compounds were determined according to the retention time and absorption spectra of peaks of standard compounds. The total area under the peak was used to quantify the phenolics.

\section{Total flavonoid content}

The total flavonoid content of the samples was determined using the colorimetric method according to Hogan et al. (2009). One $\mathrm{mL}$ of extract was mixed with $0.3 \mathrm{ml}$ of $\mathrm{NaNO}_{2}$, $0.3 \mathrm{ml}$ of $\mathrm{AlCl}_{3}$ and $2 \mathrm{ml}$ of $\mathrm{NaOH}$ respectively. The absorbance of the mixtures was recorded at $510 \mathrm{~nm}$ using a spectrophotometer.

\section{Mineral content \\ After $5 \mathrm{~g}$ of grape samples had been dried in a drying cabinet at $70^{\circ} \mathrm{C}$, about $0.5 \mathrm{~g}$ of the sample was digested in a closed microwave system by using $5 \mathrm{ml}$ of $65 \% \mathrm{HNO}_{3}$ and $2 \mathrm{ml}$ of $35 \% \mathrm{H}_{2} \mathrm{O}_{2}$. After $20 \mathrm{ml}$ ultra-deionised water was added to the digested sample, the sample was analysed by ICP AES (Varian-Vista, Australia) for minerals (Skujins, 1998).}

\section{Oil extraction}

Oil was extracted from the ground seeds with petroleum ether in a Soxhlet apparatus for $6 \mathrm{~h}$. The solvent (petroleum ether) was then evaporated (AOAC, 1990). The obtained oil was kept in coloured bottles at $-18^{\circ} \mathrm{C}$ until analysis.

\section{Fatty acid composition}

The oil sample (50 to $100 \mathrm{mg}$ ) was converted to its fatty acid methyl esters (FAME). The fatty acid methyl esters were identified by comparing the retention time of the samples and appropriate standards of fatty acids methyl esters (AOAC,

TABLE 1

Colour of pulp and properties

\begin{tabular}{lll}
\hline Grape & Colour of pulp & Properties \\
\hline Çavuş & Yellow-green & Table grape, light oval, very coarse grained, specific flavour \\
Çınarlı Karası & Black & Table grape, round-elliptical, coarse-grained, neutral flavour \\
Kalecik Karası & Blue-black & Wine grape, round, medium grains, specific flavour \\
Red Globe & Pink-red & Table grape, round-elliptical, very coarse-grained, neutral flavour \\
Trakya İlkeren & Blue-black & Table grape, round, very coarse-grained, neutral flavour \\
Yalova İncisi & Green-yellow & Table grape, light-elliptical, very coarse-grained, neutral flavour \\
Yapıncak & White-yellow & Both table and wine grapes, elliptical, coarse-grained, specific flavour \\
\hline
\end{tabular}

Ten kg of random grape samples were harvested at the mature stage of the grapes. Grapes were brought to the laboratory in a cooler and cut down the middle with a knife. Pulp+skin (seedless parts) and seeds were separated manually. The seeds of the grapes were cleaned using distilled water and then dried in an oven (Nüve FN055 Ankara, Turkey) at $40^{\circ} \mathrm{C}$ until a constant weight was obtained. Seeds were stored at $+4^{\circ} \mathrm{C}$; the pulp and skin parts were frozen at $-80^{\circ} \mathrm{C}$ until analysis. 
1990). The fatty acid methyl esters were injected into a gas chromatograph (Shimadzu GC-2010) with a capillary column, CP-Sil 88 (100 m long, $0.25 \mathrm{~mm}$ ID, film thickness $0.2 \mu \mathrm{m}$ ) and flame-ionisation detector (FID).

\section{Tocopherol content}

Tocopherol content was measured according to Spika et al. (2015). About $0.1 \mathrm{~g}$ of oil was dissolved in $10 \mathrm{ml}$ of $n$-hexane and filtered through a $0.45 \mu \mathrm{m}$ nylon filter. HPLC analyses of tocopherols were done using a Shimadzu-HPLC equipped with a PDA detector and LiChroCART Silica 60

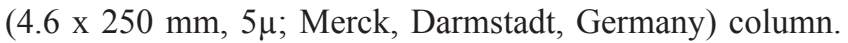
Tocopherols were separated by isocratic chromatography using a mobile phase of $0.7 \%$ propan-2-ol in $n$-hexane. The flow rate of the mobile phase was $0.9 \mathrm{ml} / \mathrm{min}$, and the injection volume was $20 \mu \mathrm{l}$. The peaks were recorded at 295 and $330 \mathrm{~nm}$ with a PDA detector. The total running time per sample was $30 \mathrm{~min}$. Standard solutions of tocopherols $(\alpha-$, $\beta$-, $\gamma$ - and $\delta$-tocopherol) were constructed at concentrations of 0 to $100 \mathrm{mg} / \mathrm{L}$. All analyses were done in triplicate.

\section{Statistical analyses}

Analysis of variance (ANOVA) using JUMP version 9.0 (SAS Inst. Inc., Cary NC, USA) and the mean \pm standard deviation (MSTAT C) of the results were calculated according to Püskülcü and İkiz (1989).

\section{RESULTS AND DISCUSSION}

The soluble solid contents (of the pulp), total dry matter (of the seeds), titratable acidity, maturation index, harvest date and some properties of grape cultivars are shown in Table 2. The highest and the lowest soluble solid contents were found in Kalecik karası $\left(22.00^{\circ}\right.$ Brix) and Red Globe $\left(15.20^{\circ}\right.$ Brix $)$ respectively $(\mathrm{p}<0.05)$. The results for titratable acidity ranged from $4.10 \mathrm{~g} / \mathrm{L}$ to $7.80 \mathrm{~g} / \mathrm{L}$. Maximum titratable acidity was determined in Kalecik karas1, while the minimum value was found in Yapıncak. The maturation index of the grape varieties at harvesttime varied from 23.40 (Yapıncak) to 47.50 (Çınarlı karası). Water-soluble dry matter, titratable acidity, maturation index and grape colour had an effect on the maturation of the grapes. The grapes can be harvested when the maturation index is a minimum of 20 (OIV, 2008). As can be seen in Table 2, the grapes used in the current experiment were harvested at the maturation stage. According to the total dry matter assay, the highest value was found in Yapincak seeds (68.27\%), while the lowest amount of dry matter was in seeds of Yalova incisi (56.38\%). According to Samoticha et al. (2017), the soluble solid contents range from $10.6^{\circ} \mathrm{Brix}$ to $22.3^{\circ} \mathrm{Brix}$ in white grapes, and from $15.2^{\circ} \mathrm{Brix}$ to $20.6^{\circ} \mathrm{Brix}$ for red grapes. The average total acidity of the white and red cultivars was 0.95 and $0.93 \mathrm{~g}$ tartaric acid/100 $\mathrm{g}$, respectively.

The antioxidant activities, total phenolic and total flavonoid contents of the grape samples are presented in Table 3. Antioxidant activities of the samples varied between $30.298 \%$ and $90.948 \%$. The total phenolic contents of the grape samples were found to be between 44.063 and $199.063 \mathrm{mg} \mathrm{GAE} / 100 \mathrm{~g}$. Trakya ilkeren had the highest total phenolic content (199.06 mg GAE/100 g), followed by Red Globe (170.313 mg GAE/100 g) and Çavuş (146.641 mg GAE/100 g). Significant differences were observed between the total phenolic contents of the grape extracts $(p<0.05)$. The total flavonoid contents of the grape varieties ranged from 0.491 to $6.810 \mathrm{mg} / \mathrm{g}$. The total flavonoid content of Red Globe $(6.810 \mathrm{mg} / \mathrm{g})$ was found to be close to that of Trakya ilkeren $(6.744 \mathrm{mg} / \mathrm{g})$. The minimum flavonoid content was determined in Yalova incisi, with a value of $0.491 \mathrm{mg} / \mathrm{g}$. Hogan et al. (2009) observed that the total phenolic and flavonoid contents of wine grapes varied between 0.68 and $1.82 \mathrm{mg} \mathrm{GAE} / \mathrm{g}$ and 0.48 and $1.19 \mathrm{mg} \mathrm{RE} / \mathrm{g}$ respectively. In another study, the total phenolic contents of both grape pulp and grape seed varied from 9.26 to $62.29 \mathrm{mg}$ GAE/100 $\mathrm{g}$ and from 162.29 to $326.18 \mathrm{mg} \mathrm{GAE} / 100 \mathrm{~g}$ respectively (Y1lmaz et al., 2015). In the experiments reported by Samoticha et al. (2017), the total phenolic content of white grapes varied from 1974.9 to $3884.4 \mathrm{mg} / 100 \mathrm{~g}$, while it ranged from 1037.0 to $5759.1 \mathrm{mg} / 100 \mathrm{~g}$ in red grapes. The degree of maturity and environmental conditions influence the amount of phenolic compounds. Moreover, the fruit parts, such as skin, pulp or seeds, exhibit different polyphenol concentrations. The antioxidant activities of grape varieties range from $93.80 \%$ to $95.62 \%$ in grape skin, from $88.16 \%$ to $94.68 \%$ in grape pulp, and from $88.10 \%$ to $94.46 \%$ in grape seeds (Farhadi et al., 2016).

Antioxidant activities, along with the total phenolic and total flavonoid contents of the grape seeds, are shown in Table 3. The antioxidant activities of the seeds varied between $86.688 \%$ and $90.974 \%$, and was higher than that found in

TABLE 2

Some Properties of Grape Varieties

\begin{tabular}{llllll}
\hline Grape varieties & Harvest date & $\begin{array}{l}\text { Soluble solid content } \\
\left({ }^{\circ} \text { Brix, pulp) }\right.\end{array}$ & $\begin{array}{l}\text { Titratable acidity } \\
(\mathrm{g} / \mathrm{L})\end{array}$ & $\begin{array}{l}\text { Maturation index } \\
(\%, \text { seed })\end{array}$ & $\begin{array}{l}\text { Total dry matter } \\
(\%)\end{array}$ \\
\hline Çavuş & $2015-09-24$ & $16.90 \pm 0.36 \mathrm{de}^{*}$ & $5.00 \pm 0.21 \mathrm{~b}$ & $34.10 \pm 0.27 \mathrm{c}$ & $62.41 \pm 1.14 \mathrm{~d}$ \\
Çınarlı Karası & $2015-09-08$ & $17.20 \pm 0.41 \mathrm{de}^{* *}$ & $7.40 \pm 0.13 \mathrm{a}$ & $23.40 \pm 0.93 \mathrm{~g}$ & $66.47 \pm 0.96 \mathrm{c}$ \\
Kalecik Karas1 & $2015-09-14$ & $22.00 \pm 0.67 \mathrm{a}$ & $7.80 \pm 0.93 \mathrm{a}$ & $28.20 \pm 0.48 \mathrm{e}$ & $66.55 \pm 1.09 \mathrm{c}$ \\
Red Globe & $2015-09-29$ & $15.20 \pm 0.73 \mathrm{e}$ & $4.60 \pm 0.87 \mathrm{c}$ & $33.20 \pm 0.51 \mathrm{~d}$ & $67.03 \pm 1.13 \mathrm{~b}$ \\
Trakya İlkeren & $2015-08-03$ & $19.40 \pm 0.27 \mathrm{~b}$ & $7.20 \pm 0.69 \mathrm{a}$ & $26.90 \pm 0.38 \mathrm{ef}$ & $59.29 \pm 0.78 \mathrm{e}$ \\
Yalova İncisi & $2015-08-14$ & $18.40 \pm 0.51 \mathrm{~d}$ & $4.50 \pm 0.57 \mathrm{c}$ & $40.90 \pm 0.41 \mathrm{~b}$ & $56.38 \pm 0.89 \mathrm{f}$ \\
Yapıncak & $2015-10-02$ & $19.60 \pm 0.84 \mathrm{~b}$ & $4.10 \pm 0.77 \mathrm{c}$ & $47.50 \pm 0.97 \mathrm{a}$ & $68.27 \pm 1.57 \mathrm{a}$ \\
\hline
\end{tabular}

* mean \pm standard deviation; ** means in the same raw with the same letters are not significantly different $(\mathrm{p}<0.05)$ 
TABLE 3

Antioxidant activity, total phenolic and total flavonoid contents of grape pulp+skin and seeds

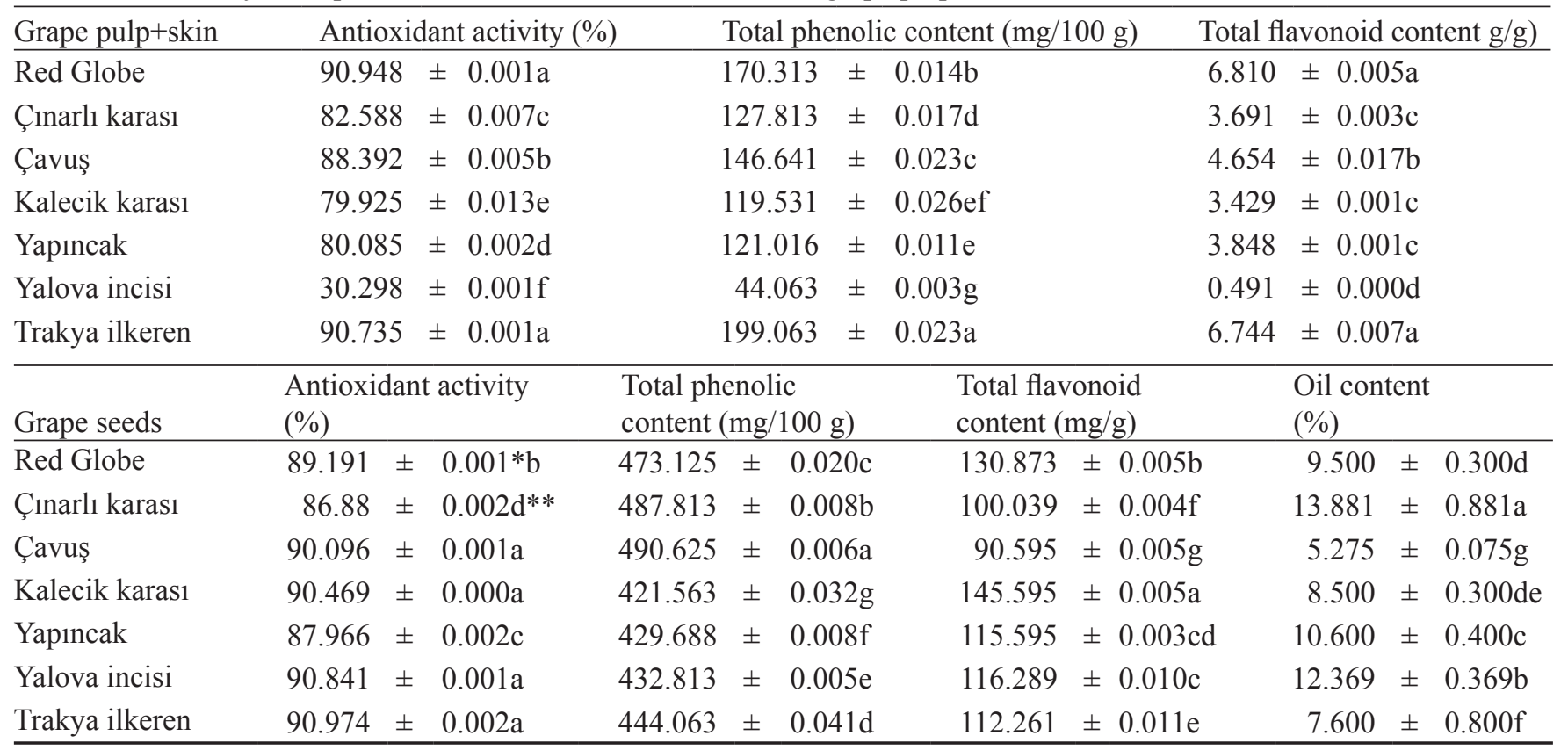

$*$ mean \pm standard deviation; $* *$ means in the same row with the same letters are not significantly different $(\mathrm{p}<0.05)$

the pulp+skin of grape. The total phenolic contents of the grape seeds ranged from 421.563 to $490.625 \mathrm{mg} \mathrm{GAE} / 100 \mathrm{~g}$, and the richest variety in terms of total phenol content was Çavuş (490.625 mg GAE/100 g), followed by Çınarlı karası (487.813 mg GAE/100 g). The total flavonoid content of the grape seeds was considerably higher compared with the rest of the grapes and was found to be between 90.595 and $145.595 \mathrm{mg} / \mathrm{g}(\mathrm{p}<0.05)$. Concerning the results, the grape seeds contained rich bioactive substances. According to Ky et al. (2014), the total phenolic content of grape seed extracts varied from 36.6 to $49.7 \mathrm{mg} \mathrm{GAE} / \mathrm{g}$, and the antioxidant activity of the seed extract of grape varieties using DPPH ranged from 117.4 to $536.2 \mu \mathrm{mol}$ Trolox/g (dry weight). The total phenolic contents of the grape seeds $(825.80$ to $3313.5 \mathrm{mg} \mathrm{GAE} / 100 \mathrm{~g}$ ) were higher than that of the pulp (50.79 to $141.72 \mathrm{mg} \mathrm{GAE} / 100 \mathrm{~g}$ ) (Anastasiadi et al., 2010).

The highest oil content was determined in Çınarlı karası $(13.881 \%)$, while the seeds of Çavuş variety $(5.275 \%)$ contained the lowest oil content. Sabir et al. (2012) reported that the oil content of grape seeds ranged from $7.3 \%$ to $22.4 \%$. In addition, the oil content of Red Globe and Kalecik Karas 1 was found to be 142.1 and $123.3 \mathrm{~g} / \mathrm{kg}$. Fernandes et al. (2013) determined that the highest and lowest oil content of grape seeds was $12.40 \%$ and $3.95 \%$ respectively. In another study, the oil content in grape seeds of wine varieties averaged at $11.60 \mathrm{~g} / 100 \mathrm{~g}$ (Lachman et al., 2015).

The phenolic compounds of the grape pulp and seeds are presented in Table 4. Generally, the main phenolic compounds of all varieties were gallic acid, 3,4-dihydroxybenzoic acid, (+)-catechin and 1,2-dihydroxybenzene. The highest gallic acid was determined in Yalova incisi $(77.832 \mathrm{mg} / 100 \mathrm{~g})$, Çınarlı karası (57.325 mg/100 g) and Kalecik karası $(49.704 \mathrm{mg} / 100 \mathrm{~g})(\mathrm{p}<0.05)$. The highest content of 3,4-dihydroxybenzoic acid was found in the Çavuş (101.462 $\mathrm{mg} / 100 \mathrm{~g})$ and Yalova incisi $(54.093 \mathrm{mg} / 100 \mathrm{~g})$ varieties. Yalova incisi $(53.776 \mathrm{mg} / 100 \mathrm{~g})$ had also the greatest content of (+)-catechin. The highest amount of 1,2-dihydroxybenzene was also observed in Yalova incisi $(95.589 \mathrm{mg} / 100 \mathrm{~g})$ and Çınarlı karası (56.357 mg/100 g). Significant differences were observed among the gallic acid, caffeic acid and rutin trihidrate contents of grape pulp extracts and between the 3.4-dihydroxybenzoic, resveratrol and isorhamnetin contents of grape seed extracts $(p<0.05)$. Moreover, apigenin 7 glucoside in Çavuş (22.995 mg/100 g), and the caffeic acid and quercetin contents in Yapıncak $(20.244 \mathrm{mg} / 100 \mathrm{~g}$ and $22.968 \mathrm{mg} / 100 \mathrm{~g}$ respectively), were found to be higher than in other varieties. The phenolic compounds of grape seeds were determined as significantly high in comparison to in the rest of the grapes. The major phenolic compounds of Red Globe were 1,2-dihydroxybenzene (445.287 mg/100 g), rutin $(202.915 \mathrm{mg} / 100 \mathrm{~g})$, apigenin 7 glucoside (194.638 $\mathrm{mg} / 100 \mathrm{~g})$ and caffeic acid $(142.473 \mathrm{mg} / 100 \mathrm{~g}) .(+)$-Catechin $(284.424 \mathrm{mg} / 100 \mathrm{~g})$, gallic acid $(221.492 \mathrm{mg} / 100 \mathrm{~g})$ and quercetin $(201.424 \mathrm{mg} / 100 \mathrm{~g})$ were highest in Çınarlı karası; 1,2-dihydroxybenzene (556.198 $\mathrm{mg} / 100 \mathrm{~g}$ and 549.264 $\mathrm{mg} / 100 \mathrm{~g}$ respectively) in Çavuş and Kalecik karası; (+)-catechin $(480.509 \mathrm{mg} / 100 \mathrm{~g}$ and $309.335 \mathrm{mg} / 100 \mathrm{~g}$, respectively) in Yapıncak and Yalova incisi; and rutin $(231.542 \mathrm{mg} / 100 \mathrm{~g})$ was found in a considerable amount in Trakya ilkeren varieties. The highest resveratrol content was observed in Çınarlı karası, with a value of $197.508 \mathrm{mg} / 100 \mathrm{~g}$. Rockenbach et al., (2011) studied phenolic compounds of different grape varieties (Cabernet Sauvignon, Merlot, Bordeaux and Isabel), and the rutin, kaempferol, catechin, epicatechin, resveratrol and gallic acid contents ranged from 12.00 to $41.43 \mathrm{mg} / 100 \mathrm{~g}$, from 0.0 to $15.09 \mathrm{mg} / 100 \mathrm{~g}$, from 94.28 to $150.16 \mathrm{mg} / 100 \mathrm{~g}$, from 0.0 to $44.36 \mathrm{mg} / 100 \mathrm{~g}$, from 
ఫृ ฮั่

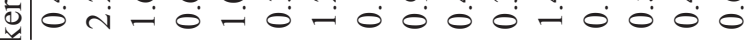

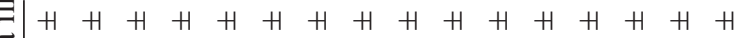

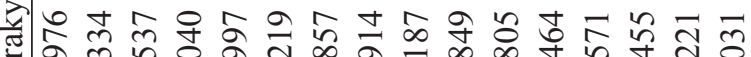
m $\sigma$ i ஸீ

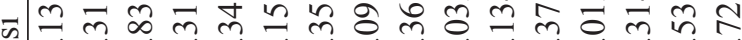

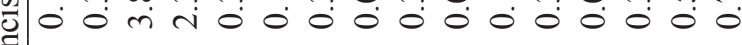
H H H H H H H H H H H H H H H ส

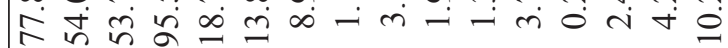

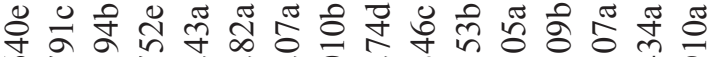
古六

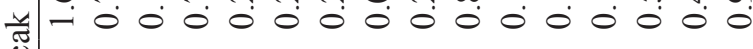
:

敉

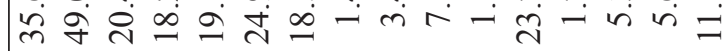

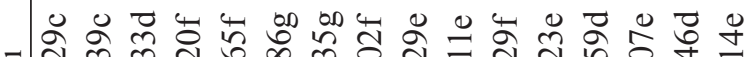
चี H H H H H H H H H H H H H H H H

ปั

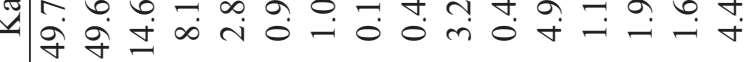

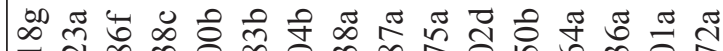

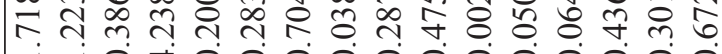

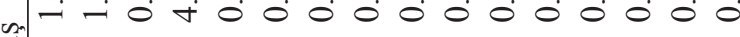
药

웅ㅎㅀ 哂 $\infty$ mे

유 ปี

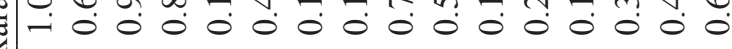

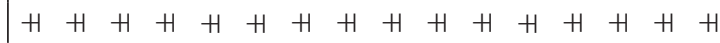

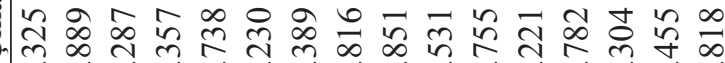
in 0 in in 世 * * *

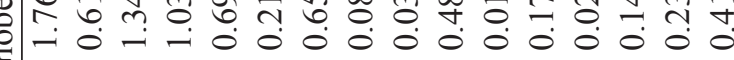
$\mathrm{H}+\mathrm{H}+\mathrm{H} H+\mathrm{H}+\mathrm{H}+\mathrm{H}+\mathrm{H}+\mathrm{H} H+$

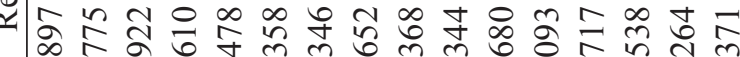

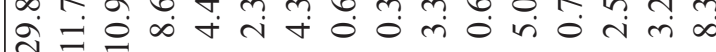

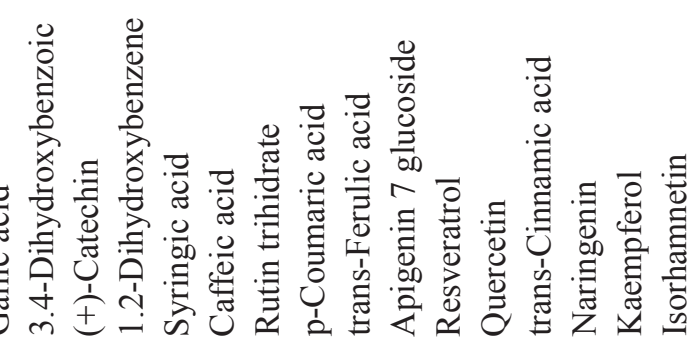

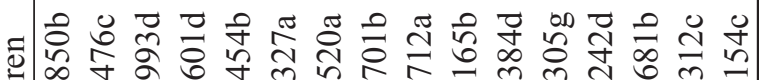

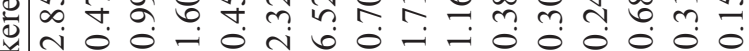
$\mathrm{H} H+\mathrm{H} H+\mathrm{H} H+\mathrm{H}+\mathrm{H}+\mathrm{H}+\mathrm{H} H$

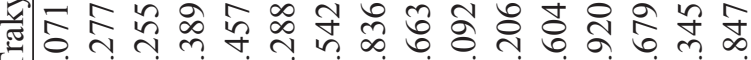

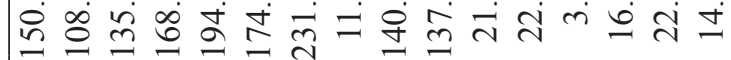

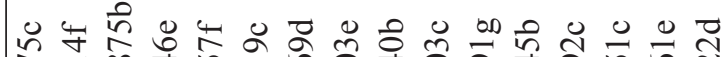

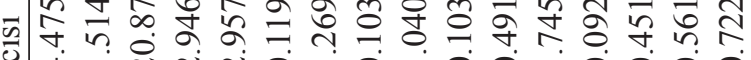

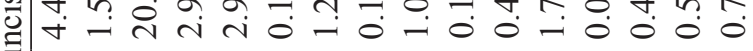

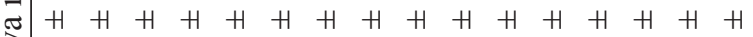
융ำ

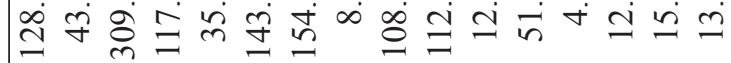

च

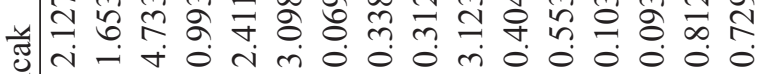

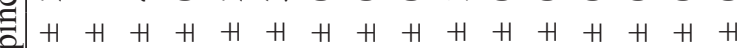
స 官市

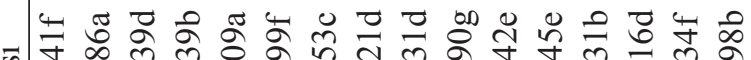
चुत ते ले के

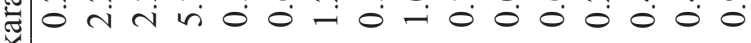
H H H H H H H H H H H H H H H H

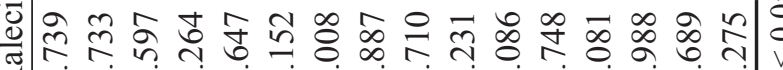

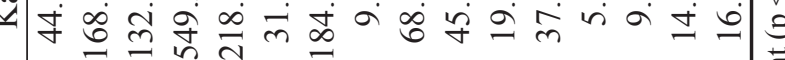
은

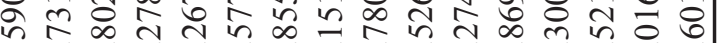

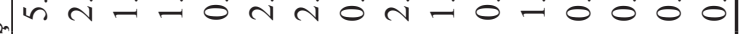
H H H H H H H H H H H H H H H H ๘ क्ष

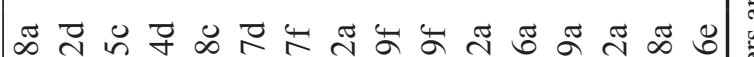

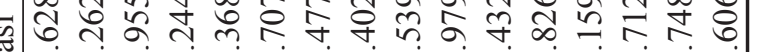

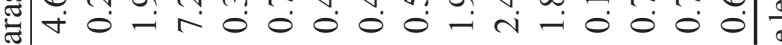

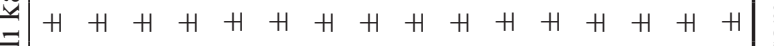

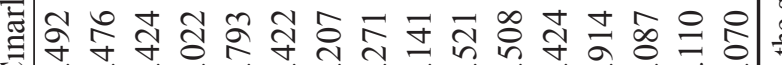

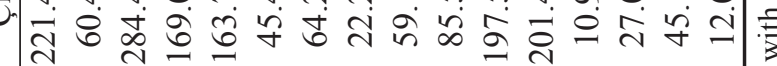

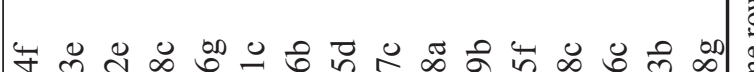

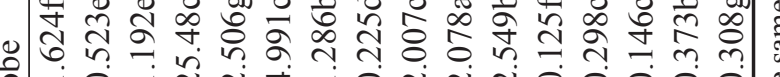
$0-10-\pi$ त H H H H H H H H H H H H H H H H đ্

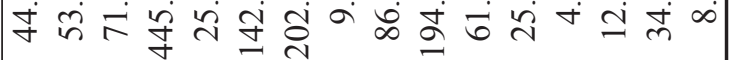

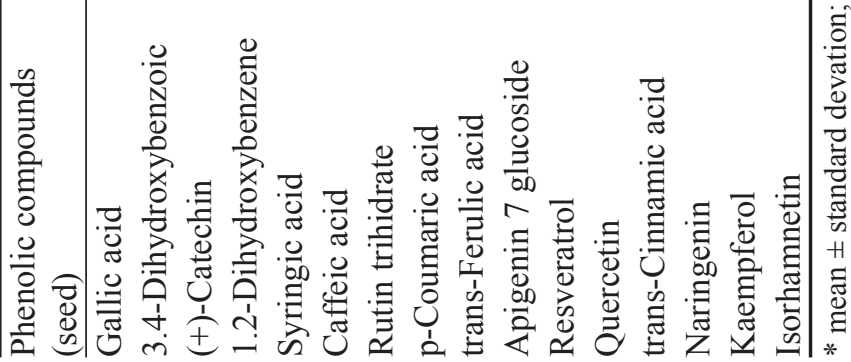


0.0 to $6.40 \mathrm{mg} / 100 \mathrm{~g}$ and from 4.59 to $18.68 \mathrm{mg} / 100 \mathrm{~g}$, respectively. The phenolic acids of wine grapes were found to be gallic acid (16.7 to $72.6 \mu \mathrm{g} / \mathrm{g}$ ), chlorogenic acid (2.1 to $3.3 \mu \mathrm{g} / \mathrm{g})$, vanillic acid (2.2 to $49.4 \mu \mathrm{g} / \mathrm{g})$, caffeic acid ( 0.1 to $9.2 \mu \mathrm{g} / \mathrm{g}$ ), coumaric acid (2.8 to $4.2 \mu \mathrm{g} / \mathrm{g}$ ) and ferulic acid (0.1 to $0.6 \mu \mathrm{g} / \mathrm{g}$ ) (Hogan et al., 2009). Anastasiadi et al. (2010) reported that the phenolic compounds of grape seeds were gallic acid ( 7.22 to $161.74 \mathrm{mg} / 100 \mathrm{~g})$, catechin (143.63 to $1067.0 \mathrm{mg} / 100 \mathrm{~g}$ ) and epicatechin $(89.21$ to 371.65 $\mathrm{mg} / 100 \mathrm{~g})$. The main phenolic compounds in the pulp of grapes were catechin (354 to $514 \mu \mathrm{g} / \mathrm{g}$ ), epicatechin (135 to $234 \mu \mathrm{g} / \mathrm{g}$ ), gallic acid (87 to $192 \mu \mathrm{g} / \mathrm{g}$ ) and quercetin (87 to $198 \mu \mathrm{g} / \mathrm{g}$ ). The gallic acid, catechin, epicatechin and quercetin contents of grape seeds were between 67 and $91 \mu \mathrm{g} / \mathrm{g}, 122$ and $156 \mu \mathrm{g} / \mathrm{g}, 103$ and $167 \mu \mathrm{g} / \mathrm{g}, 25$ and $38 \mu \mathrm{g} / \mathrm{g}$ respectively (Farhadi et al., 2016).

The fatty acid composition of the grape seed oils is shown in Table 5. Grape seeds are a good source of essential fatty acids, and their linoleic acid contents varied between $66.94 \%$ and $77.359 \%$. Significant differences were observed among the linoleic acid contents of grape seed oils $(p<0.05)$. The amount of oleic acids of seed oils ranged from $10.746 \%$ to $19.660 \%$. Palmitic and stearic acids varied between $7.176 \%$ and $10.358 \%$ and $2.983 \%$ and $5.435 \%$ respectively $(p<0.05)$. The highest linoleic and the lowest oleic acid contents were found in the Çavuş variety. Furthermore, the linolenic acid content of seed oils was below 1\%. According to Lachman et al. (2015), linoleic acid was the most prominent fatty acid and was observed at between 68.10 and $78.18 \mathrm{~g} / 100 \mathrm{~g}$. In another study, the major fatty acid of seed oils was linoleic acid $(53.6 \%$ to $69.6 \%)$, followed by oleic $(16.2 \%$ to $31.2 \%)$, palmitic $(6.9 \%$ to $12.9 \%)$ and stearic $(1.44 \%$ to $4.69 \%)$ acids The oils of Red Globe and Kalecik Karası seeds contained high levels of linoleic acid, with values of $68.8 \%$ and $63.7 \%$ respectively (Sabir et al., 2012). The oil contents of the grape seeds ranged from $12.09 \%$ (Kalecik karasi) to $17.08 \%$ (Gamay), and the main fatty acids were linoleic $(66.69 \%$ to $72.50 \%$ ), oleic $(13.13 \%$ to $18.50 \%)$ and palmitic acids (6.87\% to $9.56 \%$ ) (Yalcin et al., 2016).

The tocopherol contents of seed oils are given in Table 4. The $\alpha$-tocopherol content of seed oils ranged from $0.137 \mathrm{mg} / \mathrm{g}$ (Red Globe) to $0.231 \mathrm{mg} / \mathrm{g}$ (Çavuş) $(p<0.05)$. The amounts of $\beta$ - and $\gamma$-tocopherols were 0.00 to $0.220 \mathrm{mg} / \mathrm{g}$ and $0.110 \mathrm{mg} / \mathrm{g}$ to $0.185 \mathrm{mg} / \mathrm{g}$ respectively. Çavuş seed oil had the highest $\alpha$-tocopherol content, while the highest $\beta$ - and $\gamma$-tocopherol contents were determined in the Trakya ilkeren variety. According to the study of Sabir et al. (2012), the $\alpha$-tocopherol content of seed oils was determined at between 260.5 and $153.1 \mathrm{mg} / \mathrm{kg}$. The $\alpha-, \beta-$, $\gamma$ - and $\delta$-tocopherol contents were 142.2, 1.29, 25.5 and $0.87 \mathrm{mg} / \mathrm{kg}$ for Red Globe seed oil, and 172.4, 0.70, 27.5 and $0.63 \mathrm{mg} / \mathrm{kg}$ for Kalecik karas1 respectively. It was reported that grape seed oils are a good source of $\alpha$-tocopherol, with the value ranging between 85.5 and $244.0 \mathrm{mg} / \mathrm{kg}$ (Fernandes et al., 2013).

The mineral contents of the seedless parts and seeds of grapes are given in Table 5. The major minerals of the seedless parts of grapes were potassium (K, 1772.615 to $4569.411 \mathrm{mg} / \mathrm{kg}$ ), calcium (Ca, 187.351 to $498.814 \mathrm{mg} / \mathrm{kg})$, phosphorus (P, 145.038 to $286.042 \mathrm{mg} / \mathrm{kg}$ ), sulphur (S,

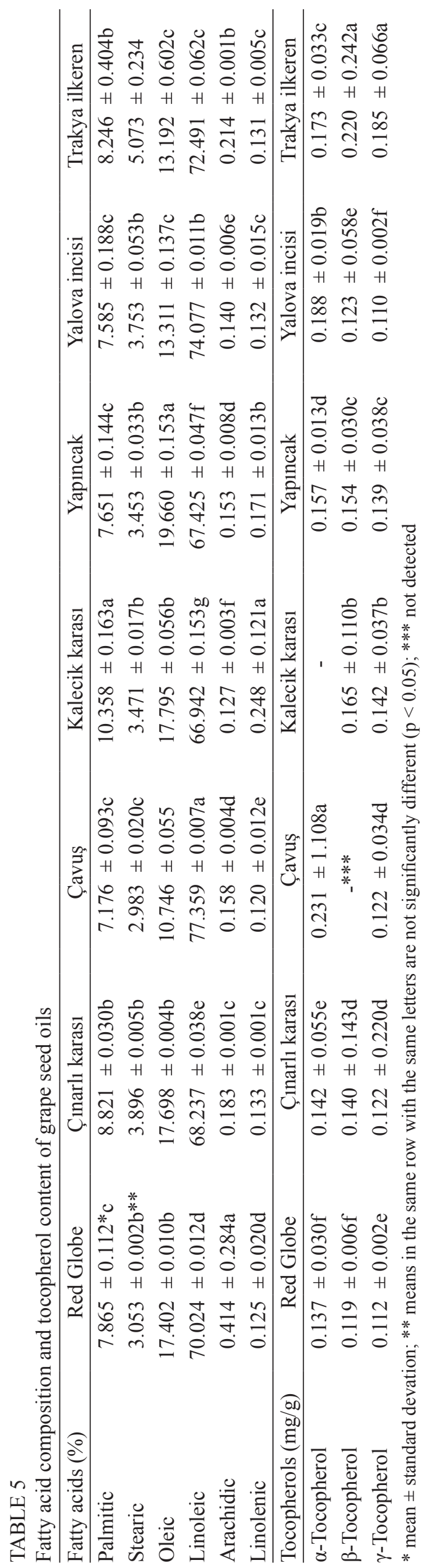




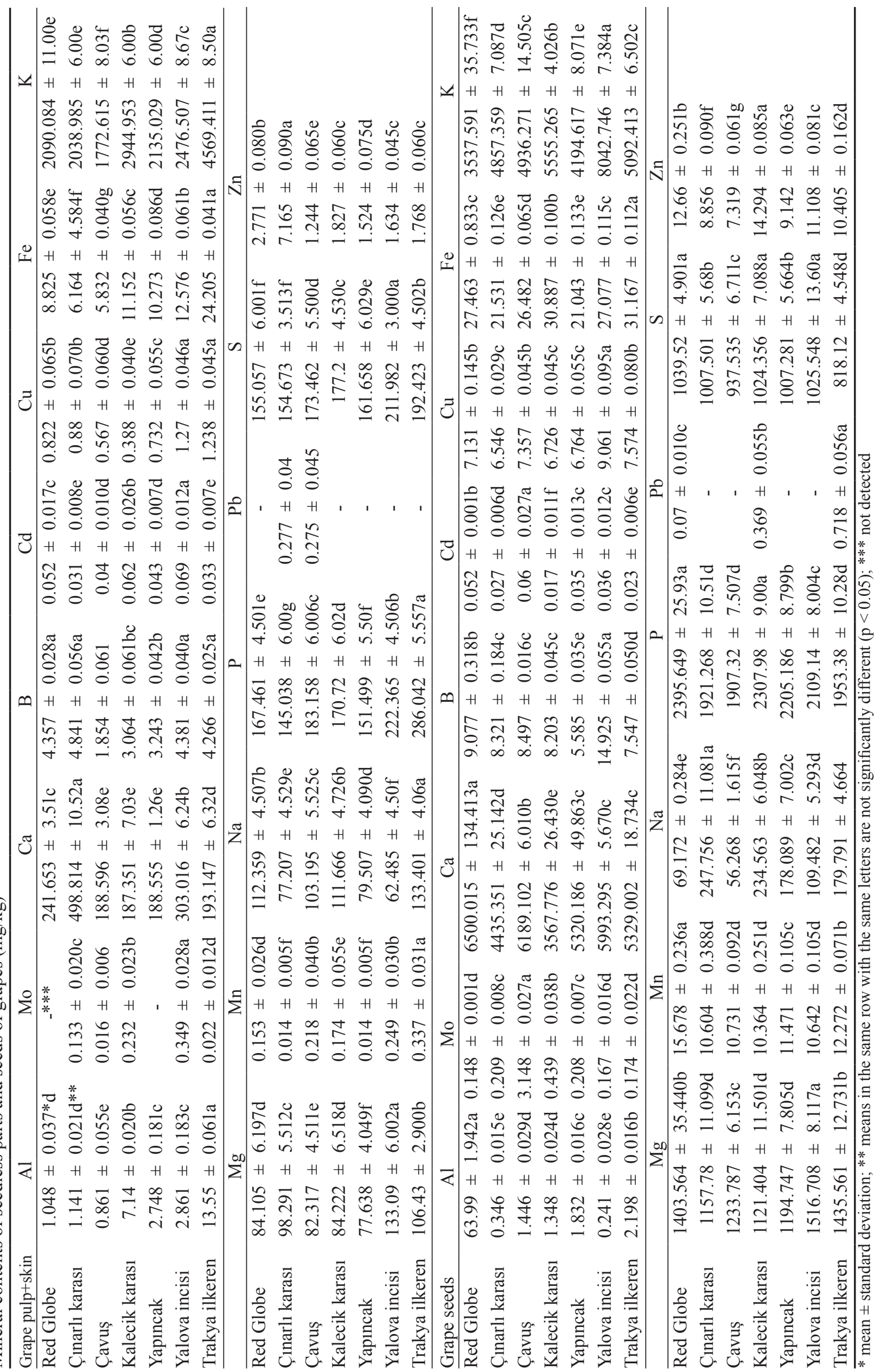


154.673 to $211.982 \mathrm{mg} / \mathrm{kg})$, magnesium $(\mathrm{Mg}, 77.638$ to $133.086 \mathrm{mg} / \mathrm{kg}$ ) and sodium ( $\mathrm{Na}, 62.485$ to $133.401 \mathrm{mg} / \mathrm{kg}$ ) $(\mathrm{p}<0.05)$. Other minerals, e.g. $\mathrm{Fe}, \mathrm{Al}, \mathrm{B}, \mathrm{Cu}, \mathrm{Cd}, \mathrm{Mo}$, $\mathrm{Zn}, \mathrm{Mn}$ and $\mathrm{Pb}$ were found at lower levels. The highest potassium content was observed in the Trakya ilkeren variety (4 $569.411 \mathrm{mg} / \mathrm{kg}$ ), followed by Kalecik karası (2 944.953 $\mathrm{mg} / \mathrm{kg}$ ). Çınarlı karası had the highest Ca content (498.814 $\mathrm{mg} / \mathrm{kg}$ ), while Yalova incisi had the maximum $\mathrm{Mg}$ content $(133.086 \mathrm{mg} / \mathrm{kg})$. The greatest amounts of P, S and Na were determined in Trakya ilkeren $(286.042 \mathrm{mg} / \mathrm{kg})$ and Yalova incisi $(211.982 \mathrm{mg} / \mathrm{kg})$. Moreover, Trakya ilkeren was the variety with the highest $\mathrm{Fe}(24.205 \mathrm{mg} / \mathrm{kg})$ and $\mathrm{Al}(13.550$ $\mathrm{mg} / \mathrm{kg}$ ) contents. Cd shows a toxic effect and was found below $1 \%$, while $\mathrm{Ni}$ and $\mathrm{Cr}$ were not detected in any of the varieties.

Macro-elements such as $\mathrm{K}, \mathrm{Ca}, \mathrm{P}, \mathrm{Mg}, \mathrm{S}$ and $\mathrm{Na}$ in the grape seeds varied between 3537.591 and 8042.746 $\mathrm{mg} / \mathrm{kg}, 3567.776$ and $6500.015 \mathrm{mg} / \mathrm{kg}, 1907.320$ and $2395.649 \mathrm{mg} / \mathrm{kg}, 1121.404$ and $1516.708 \mathrm{mg} / \mathrm{kg}, 818.120$ and $1039.520 \mathrm{mg} / \mathrm{kg}$, and 56.268 and $247.756 \mathrm{mg} / \mathrm{kg}$ respectively $(\mathrm{p}<0.05)$. The mineral contents of the grape seeds were higher than in the rest of the grape. The highest $\mathrm{Ca}, \mathrm{P}$ and $\mathrm{S}$ were observed in Red Globe seeds, with values of $6500.015 \mathrm{mg} / \mathrm{kg}, 2395.649 \mathrm{mg} / \mathrm{kg}$ and $1039.520 \mathrm{mg} / \mathrm{kg}$ respectively $(\mathrm{p}<0.05)$. The seeds of Yalova incisi had the highest $\mathrm{K}(8042.746 \mathrm{mg} / \mathrm{kg}$ ) and $\mathrm{Mg}(1516.708 \mathrm{mg} / \mathrm{kg}$ ) contents. In addition, grape seeds did not contain $\mathrm{Ni}$ and $\mathrm{Cr}$, although $\mathrm{Cd}$ was found at levels below $1 \%$, similar to in the grape pulp+skin. In the experiments of Aykut (2002), the mineral composition of the different grape varieties (Sultani, Hamburg Misketi and Alicante Bouschet) was as follows: K (1 255 to $1750 \mathrm{mg} / \mathrm{kg}$ ), Ca (24 to $34 \mathrm{mg} / \mathrm{kg}$ ), Mg (53.75 to $102.5 \mathrm{mg} / \mathrm{kg}$ ), Na (31.32 to $53.30 \mathrm{mg} / \mathrm{kg}), \mathrm{P}$ (97.20 to 168.2 $\mathrm{mg} / \mathrm{kg}), \mathrm{Fe}$ (0.71 to $1.88 \mathrm{mg} / \mathrm{kg}), \mathrm{Cu}(0.8$ to $2.5 \mathrm{mg} / \mathrm{kg}), \mathrm{Zn}$ $(0.35$ to $0.79 \mathrm{mg} / \mathrm{kg})$ and $\mathrm{Mn}(0.49$ to $1.45 \mathrm{mg} / \mathrm{kg})$.

Some differences were observed in the results when compared with the literature. These differences could probably be due to variety, cultural factors and analytical conditions. Grape pulp and seeds are very important for human health because of phenolics, fatty acids, tocopherols, minerals and bioactive properties.

\section{CONCLUSIONS}

Grape and grape products are important foods due to their richness in bioactive components. Many studies emphasise the importance of grapes and their products, which are sources of natural antioxidants, for health. Therefore, it is necessary to investigate the physicochemical properties and bioactive components of local varieties as well as international varieties. For this purpose, this study was performed to determine the bioactive compounds of both the seeds and the seedless parts of different grape varieties. In addition, the oil content, fatty acid composition and tocopherol content of seeds were investigated. Of all the grape varieties, Red Globe and Trakya Ilkeren have the highest antioxidant activities (90.948\%, 90.735\%), and total phenolic $(170.313 \mathrm{mg} / 100 \mathrm{~g}, 199.063 \mathrm{mg} / 100 \mathrm{~g})$ and total flavonoid $(6.810 \mathrm{mg} / \mathrm{g}, 6.744 \mathrm{mg} / \mathrm{g})$ contents. The seedless parts of the grapes (pulp+skin) exhibited lower phenolic, flavonoid and mineral contents than the seeds of the grapes.
Furthermore, the main fatty acid was linoleic acid (66.942 to $77.359 \%$ ), and $\alpha$-tocopherol was the most abundant isomer $(0.137$ to $0.231 \mathrm{mg} / \mathrm{g})$. The mineral contents of the grape varieties also were compared. Grapes are a significant source of $\mathrm{K}, \mathrm{Ca}$ and $\mathrm{P}$.

\section{LITERATURE CITED}

Akın, A. \& Altındişli, A., 2011. Determination of fatty acid composition and lipid content of some grape cultivar seeds in Turkey. Biyol. Bil. Araş. Derg. 4, 13-15.

Anastasiadi, M., Pratsinis, H., Kletsas, D., Skaltsounis, A. \& Haroutounian, S.A., 2010 Bioactive non-coloured polyphenols content of grapes, wines and vinification by-products: Evaluation of the antioxidant activities of their extracts. Food Res. Int. 43, 805-813.

AOAC, 1990 ( $15^{\text {th }}$ ed). Official methods of analysis. Association of Official Analytical Chemists, Washington DC.

Aykut, O. 2002. Ülkemiz Ekonomisinde Yeri Olan Üzüm Çeşitleri ile Ürünlerinin Mineral Madde İçerikleri ve Değişimi Etkileyen Faktörler (Master's thesis). Ankara University, Institute of Science and Technology, Ankara.

Cemeroğlu, B. 1992. Fundamental fruit and vegetable analysis methods in industry (Meyve ve Sebze İşleme Endüstrisinde Temel Analiz Metotları). Biltav Yay., Ankara. (in Turkish).

Crews, C., Hough, P., Godeard, J., Brereton, P., Lees, M., Guiet, S. \& Winkelmann, W., 2006. Quantitation of the main constituents of some authentic grape-seed oils of different origin. J. Agric. Food Chem. 54, 62616265 .

Farhadi, K., Esmaeilzadeh, F., Hatami, M., Forough, M. \& Molaie, R., 2016. Determination of phenolic compounds content and antioxidant activity in skin, pulp, seed, cane and leaf of five native grape cultivars in West Azerbaijan province, Iran. Food Chem. 199, 847-855.

Fernandes, L., Casal, S., Cruz, R., Pereira, J.A. \& Ramalhosa, E., 2013. Seed oils of ten traditional Portuguese grape varieties with interesting chemical and antioxidant properties. Food Res. Int. 50, 161-166.

Georgiev, V., Ananga, A. \& Tsolova, V., 2014. Recent advances and uses of grape flavonoids as nutraceuticals. Nutr. 6, 391-415.

Gomez-Alonso, S., Garcia-Romero, E. \& Hermosin-Gutierrez, I., 2007. HPLC analysis of diverse grape and wine phenolics using direct injection and multidetection by DAD and fluorescence. J. Food Comp. Anal. 20, 618626.

Hassanein, M.M.M. \& Abedel-Razek, A.G., 2009. Chromatographic quantitation of some bioactive minor components in oils of wheat germ and grape seeds produced as by-products. J. Oleo Sci. 58, 227-233.

Hogan, S., Zhang, L., Li, J., Zoecklein, B. \& Zhou, K., 2009. Antioxidant properties and bioactive components of Norton (Vitis aestivalis) and Cabernet Franc (Vitis vinifera) wine grapes. LWT - Food Sci. Technol. 42, 1269-1274

Kamel, B.B., Dawson, H. \& Kakuda, Y., 1985. Characteristics and composition of melon and grape seed oils and cakes. J. Am. Oil Chem. Soc. $62(5), 881-883$

Ky, I., Lorrain, B., Kolbas, N., Crozier, A. \& Teissedre, P.L., 2014. Wine by-products: Phenolic characterization and antioxidant activity evaluation of grapes and grape pomaces from six different French grape varieties. Molecules 19, 482-506.

Lachman, J., Hejtmankova, A., Taborský, J., Kotíkova, Z., Pivec, V., Stralkova, R., Vollmannova, A., Bojnanska, T. \& Dedina, M., 2015. Evaluation of oil content and fatty acid composition in the seed of grapevine varieties. LWT - Food Sci. Technol. 63, 620-625. 
Lee, S.K., Mbwambo, Z.H., Chung, H.S., Luyengi, L., Games, E.J.C. \& Mehta, R.G., 1998. Evaluation of the antioxidant potential of natural products. Comb. Chem. High Throughput Screen. 1, 35-46.

Lutterodt, H., Slavin, M., Whent, M., Turner, E. \& Yu, L., 2011. Fatty acid composition, oxidative stability, antioxidant and antiproliferative properties of selected cold-pressed grape seed oils and flours. Food Chem. 128, 391399.

Nile, S.H., Kim, S.H., Ko, E.Y. \& Park, S.W., 2013. Polyphenolic contents and antioxidant properties of different grape $(V$. vinifera, $V$. labrusca, and $V$. hybrid) cultivars. BioMed Res. Int. 1-5, http://dx.doi. org/10.1155/2013/718065

Obreque-Slier, E., Peña-Neira, A., López-Solís, R., Zamora-Marín, F., Ricardo-da Silva, J.M. \& Laureano, O., 2010. Comparative study of the phenolic composition of seeds and skins from Carménère and Cabernet Sauvignon grape varieties (Vitis vinifera L.) during ripening. J. Agric. Food Chem. 58, 3591-3599.

OIV, 2008. Standard on minimum maturity requirements for table grapes. RESOLUTION VITI 1/2008. OIV, Paris.

Püskülcü, H. \& İkiz, F., 1989. Introduction to statistics. Bilgehan Press, Bornova, İzmir, Turkey (in Turkish).

Rockenbach, I.I., Gonzaga, L.V., Rizelio, V.M., Gonçalves, A., Genovese, M.I. \& Fett, R., 2011. Phenolic compounds and antioxidant activity of seed and skin extracts of red grape (Vitis vinifera and Vitis labrusca) pomace from Brazilian winemaking. Food Res. Int. 44, 897-901.

Sabir, A., Unver, A. \& Kara, Z., 2012. The fatty acid and tocopherol constituents of the seed oil extracted from 21 grape varieties (Vitis spp.). J. Sci. Food Agric. 92, 1982-1987.
Samoticha, J., Wojdylo, A. \& Golis, T., 2017. Phenolic composition, physicochemical properties and antioxidant activity of interspecific hybrids of grapes growing in Poland. Food Chem. 215, 263-273.

Shi, P.B., Yue, T.X., Ai, L.L., Cheng, Y.F., Meng, J.F., Li, M.H. \& Zhang, Z.W., 2016. Phenolic compound profiles in grape skins of Cabernet Sauvignon, Merlot, Syrah and Marselan cultivated in the Shacheng Area (China). S. Afr. J. Enol. Vitic. 37, 132-138.

Skujins, S., 1998. Handbook for ICP-AES (Varıan-Vista). A short guide to Vista series ICP-AES Operation. Varian Int. AGş Zug. Version 1.0, Switzerland.

Spika, M.J., Kraljic, K., Koprivnjak, O., Skevin, D., Zanetic, M. \& Katalinic, M., 2015. Effect of agronomical factors and storage conditions on the tocopherol content of Oblica and Leccino virgin olive oil. J. Am. Oil Chem. Soc. 92, 1293-1301.

Wie, M., Sung, J., Choi, Y., Kim, Y., Jeong, H-S. \& Lee, J., 2009. Tocopherols and tocotrienols in grape seeds from 14 cultivars grown in Korea. Eur. J. Lipid Sci. Technol. 11, 1256-1258.

Yalcin, H., Kavuncuoglu, H., Ekici, L. \& Sagdic, O., 2016. Determination of fatty acid composition, volatile components, physico-chemical and bioactive properties of grape (Vitis vinifera) seed and seed oil. J. Food Process. Preserv. 41(2). doi:10.1111/jfpp.12854.

Yılmaz, Y., Göksel, Z., Erdoğan, S.S., Öztürk, A., Atak, A. \& Özer, C., 2015. Antioxidant activity and phenolic content of seed, skin and pulp parts of 22 grape (Vitis vinifera L.) cultivars (4 common and 18 registered or candidate for registration). J. Food Process. Preserv. 39, 1682-1691.

Yoo, K.M., Lee, K.W., Park, J.B., Lee, H.J. \& Hwang, I.K., 2004. Variation in major antioxidants and total antioxidant activity of Yuzu (Citrus junos Sieb. ex Tanaka) during maturation and between cultivars. J. Agric. Food Chem. 52, 5907-5913. 